\title{
Reviewing the Challenges of Implementing Formative Assessment in Asia: The Need for a Professional Development Program
}

\author{
Nguyen Thi Do Quyen (Corresponding author) \\ School of Education Studies, Universiti Sains Malaysia \\ 11800 USM, Penang, Malaysia \\ Tel: 60-142-409-802Ｅ-mail: doquyen.cdtm@gmail.com
}

\begin{abstract}
Ahmad Zamri Khairani
School of Education Studies, Universiti Sains Malaysia

11800 USM, Penang, Malaysia

Tel: 60-4653-2965Ｅ-mail: ahmadzamri@usm.my
\end{abstract}

Received: July 11, 2016 Accepted: November 6, 2016 Published: November 7, 2016

doi: 10.5296/jsss.v4i1.9728 URL: http://dx.doi.org/10.5296/jsss.v4i1.9728

\begin{abstract}
This paper aims to review research on the challenges of implementing formative assessment in Asian classrooms. Multiple electronic databases were used to search for relevant articles and twenty-one studies were selected. The challenges faced while conducting formative assessments were analyzed and categorized into three levels (micro-, meso- and macro- level) based on Kozma's model, which examines contextual factors influencing teachers' classroom instructional practice as well as inherent disadvantages of formative assessment, namely, being time-consuming and demanding a heavy workload. The findings showed that the majority of challenges were on the micro and macro-levels, and were basic formative assessment disadvantages. Significantly, 80 percent of the studies reviewed reported inadequate knowledge of formative assessment among teachers at the micro-level. This is a vital issue for future research on formative assessment in Asian countries and highlights the
\end{abstract}


need to draw more attention to training teachers through effective professional development programs. Future studies in this area should focus on practical formative assessment activities to reconcile formative assessment theories within the Asian culture and conditions.

Keywords: Formative assessment, Summative assessment, Challenge, Asia

\section{Introduction}

The rapid changes in technology and globalization have affected the $21^{\text {st }}$-century education. These changes have made the modern world unpredictable. As a result, learners' skills and competencies from previous generations might not suitable any more (Hoskins \& Fredriksson, 2008). To adapt to this new era, modern learners are required to master independent learning and lifelong learning skills. For example, they might engage in social interactions, critically evaluate new knowledge with their existing skills, develop new strategies and solve problems in order to learn new knowledge (Crick, Broadfoot, \& Claxton, 2004; Hoskins \& Fredriksson, 2008; OECD, 2008).

An increasing number of studies have explored the potential of formative assessment in meeting these requirements (Clark \& Li, 2013; OECD, 2005, 2008). Hutchinson and Hayward (2005) described the interest in formative assessment as a "quiet revolution" transforming all levels of education around the world. Many Asian countries have deployed this innovation to maintain or improve student performances at the international level. For instance, PISA (The Programme for International Student Assessment and TIMSS (Trends in International Mathematics and Science Study) (Klenowski, 2009; Mok \& Chan, 2002; Ratnam-Lim, Heng, \& Tan, 2015). In terms of educational policy, various educational assessment policies have highlighted the role of formative assessment in this region. These policies, for example, are "The Outlines for Basic Educational Reform" (2001) in China; "The Basic Competency Assessment" for primary education and "School-based Assessment" for secondary education (2001) in Hong Kong; and "Holistic Assessment" (2009) in Singapore (Berry, 2011a; Ratnam-Lim et al., 2015; Yin \& Buck, 2013).

In contrast with conscious top-down assessment policy, the application of formative assessment in Asian classrooms is challenging. Many barriers concerning local contextual factors and formative assessment risks have been found in this context. Indeed, teaching, learning and assessment activities are strongly influenced by examination-oriented culture which runs counter to formative assessment principles. While "teaching students how to learn" is the main objective of formative assessment, local teachers are also required to "teach to test" in order to ensure students' high achievement in summative assessments (Black, 2015; Carless, 2012; Yin \& Buck, 2015). In addition, students prefer teachers' feedback rather than that of their peers, due to the strong Confucian-based cultural belief that knowledge mastery belongs to the teacher. Thus, peer-assessments may be seen as less useful in such cultures (Pham \& Renshaw, 2015; Tepsuriwong \& Bunsom, 2013; Yan \& Cheng, 2015). Although some formative assessment studies reported the positive effects on Asian student learning (Chin \& Teou, 2010; Lam, 2013; Ng, 2014), enormous difficulties impede formative assessment as an integral part of teaching and learning in Asian classrooms. 
Apart from that, prior research related to formative assessment practice explicitly concentrates on problems in East Asian countries, such as China, Hong Kong, and Taiwan (Berry, 2011a, 2011b; Carless, 2005), or discusses general barriers to its implementation in this region (Kennedy, 2007). However, there is a lack of attention to a broad range of challenges faced by formative assessment studies in Asian classroom realities. To address this gap, this paper aims to review the possible challenges of formative assessment implementation in the Asian classrooms and investigate which challenges may prevail. The findings of this study are expected to greatly assist Asian policymakers, educators and future researchers in identifying effective solutions for successful implementation of formative assessment in the local Asian educational settings.

\section{Different Terms for Formative Assessment}

The terminology "formative assessment" was first used by Bloom, Hastings, and Madaus (1971). This term referred to the feedback and correctives provided to both students and teachers in the teaching - learning process. However, until Black and Wiliam (1998) published their paper "Inside the Black Box: Raising Standards through Classroom Assessment", the role of formative assessment in effective teaching and learning was emphasized in the current educational setting. In their research, formative assessment was defined as: "We use the general term assessment to refer to all those activities undertaken by teachers - and by their students in assessing themselves - that provide information to be used as feedback to modify teaching and learning activities. Such assessment becomes formative assessment when the evidence is actually used to adapt the teaching to meet student needs" (Black \& Wiliam, 1998, p. 140).

However, the term "formative assessment" took on different meanings and was applied to different practices by various subsequent authors. Some authors (e.g. The Assessment Reform Group (ARG) in the UK) prefer the term "assessment for learning" to provide a clearer understanding, replacing the term "formative" which lends itself to ambiguous interpretations (Wiliam, 2011). In practice, there are five key strategies for teacher and students practicing formative assessment in classroom: (1) Clarifying and sharing learning intentions and criteria for success; (2) Engineering effective classroom discussions and other learning tasks that elicit evidence of student understanding; (3) Providing feedback that moves learners forward; (4) Activating students as instructional resources for one another; and (5) Activating students as the owners of their learning.(Wiliam \& Thompson, 2008).

Nevertheless, formative assessment practice is also strongly influenced by the local context where teachers and students engage in social interaction. As Bennett (2011) emphasized, the educational context must be taken into account in formative assessment practices due to its critical role in the overall assessment system. Furthermore, from a socio-cultural learning perspective, formative assessment can be seen as a highly contextualized and situated activity. In which teachers and students interact with each other, and the learners are encouraged to participate in the community. McMillan (2003) also claimed that classroom realities, parents, policies and high-stakes testing were some factors determining the assessment decision-making of teachers. 


\section{Three Levels of Contextual Factors Influencing Teacher's Classroom Instructional Practices}

As indicated earlier, the learning context has considerable influence on formative assessment practices. Kozma (2003) suggests three levels of interacting contextual factors concentrating on teachers' practice in the classroom: micro, meso and macro (as cited in Fulmer, Lee, \& Tan, 2015). These levels are based on research in educational technology and contextual factors influencing teachers' adoption of technology and related teaching strategies.

The micro-level is the immediate context of the classroom with varied classroom-level influences. This can consist of the individual factors generated by the teacher and students (e.g. teachers' assessment knowledge, values, and beliefs; students' prior performance in a particular area), as well as social factors related to the teacher - student interaction in the environment (e.g. the way students respond to formative assessment tasks). Technology and tools assessing within the classroom also play a role, for example, the use of clickers, whiteboards, and other materials.

The meso-level comprises of factors outside the classroom which directly influence the classroom. This level is usually defined as school level, with factors such as school policies and support from school authorities for assessment, the school's climate for supporting assessment practices, and school-wide access to tools and support staff involved in the processes of assessment. In addition, there are also other factors beyond the school environment that have an influence on the classroom, such as requests and expectations from parents and the community.

The macro-level encompasses factors that may affect the meso-level, and indirectly affect the classroom. Depending on the circumstances of the education system, macro-level factors can be varied. This includes education policies at the national level, state level, and district level related to the educational governance structure. In private and parochial schools, these factors include policies and statements from the school's affiliated social institutions. Cultural norms concerning education and assessment as well as social and economic pressures are other macro-level factors.

Despite these three levels being separated for analytic purposes, contextual factors may influence each other in various ways that are not easily predicted. According to Hofstede (2001), macro-level cultural norms and values are able to influence institutions, organizations, and individuals, both inside and outside the classroom. In other words, their influence must be understood within a broader context. To simplify our understanding, the broad national and cultural factors are still categorized at the macro-level, keeping in mind that they may also affect all levels. Finally, all challenges discerned in the reviewed studies will be analyzed in accordance with Kozma's approach.

\section{Method}

\subsection{Selection Criteria}

Seven keywords related to the formative assessment were chosen in the literature search due 
to the diverse meanings given to the term "formative assessment" by researchers. Moreover, formative assessment can be understood as strategies for doing formative assessment, inclusive of all strategies or focusing on one particular strategy, depending on the study in question (Andersson, 2015). Therefore, in searching for relevant published studies for this review, the author used the term formative assessment and two other alternative terms (classroom assessment and assessment for learning), as well as four strategies (feedback, self-assessment, peer-assessment, and self-regulation). The studies were selected based on four criteria:

(1) The study implemented formative assessment at all Asian school levels from primary to college. No formative assessment studies conducted in Western education institutions were included.

(2) The meaning of formative assessment used in the study must be related to learning activities in which teachers elicited information about student learning to improve learning and instruction. This criterion excluded studies using the term formative assessment to refer to ongoing teaching evaluation (Wei, 2015)

(3) The study was designed as a qualitative or quantitative study collecting data from participants involving formative assessment at school as teachers, students, parents or school administrators. This requirement excluded all review papers on formative assessment practice in the Asian region (Berry, 2011b; Carless, 2005; J. Chen, 2015; Kennedy, 2007).

(4) The study examined direct feedback between teachers and students in classroom activities. Such studies using interactive feedback via technological devices were excluded, such as computer-based formative assessment (Hodgson \& Pang, 2012; Hung, Lin, \& Hwang, 2010; Jingzheng \& Yuanbing, 2014; Wen \& Tsai, 2006) and a study on mobile formative assessment by Hwang (2011).

\subsection{Data Sources and Search Strategies}

This paper reviews published formative assessment studies in the Asian region. An extensive literature search on formative assessment was conducted to shortlist and select the relevant publications. Multiple electronic databases including EBSCO, JSTOR, Google Scholar, Scopus, ISI Web of Knowledge, ProQuest and Science Direct were scanned for a broad search using the seven search keywords mentioned in Section 2.1. The search results were limited to just studies implemented in Asian countries. Next, the reference lists of select articles were examined to identify further possible additions. Finally, based on the inclusion and exclusion criteria, the author selected the most relevant studies for the purpose of this review.

\subsection{Analysis}

A total of twenty-one studies which met the criteria for inclusion is presented in Table 1. The studies were sorted by published years and followed by specific characteristics such as authors' names, country, school level, and challenge categories of formative assessment practice in Asia. 
Based on Kozma's three levels approach, the challenges faced during the implementation of formative assessment in all twenty-one studies were analyzed and categorized into micro, meso and macro levels. In addition, there are two main obstacles to formative assessment that most studies in this field describe, even in non-Asian formative assessment studies, its time-consuming nature and demanding workload (Akom, 2010; Asghar, 2009; Falk, 2011; Jackson \& Marks, 2015; OECD, 2005). When implementing formative assessment in the classroom, teachers were required to do additional work (e.g., eliciting student learning information, comparing learning outcomes, giving feedback, adjusting instructions) in order to satisfy the learning needs of individual students. Therefore, the author added an additional column in this table to account for these two obstacles. The records of challenges mentioned in each study will be indicated by a "+" sign in the table's row. The following section addresses challenges and barriers found in Asian formative assessment studies and which challenges are prevailing.

\section{Findings and Discussion}

Overall, the results indicate that the vast majority of records are at the micro and macro levels, and the two primary barriers to formative assessment. It is noteworthy that $80 \%$ of the reviewed papers (17/21) claimed that teacher knowledge was the most important factor in improving the practice of formative assessment in Asian classrooms. Other factors that acted as barriers to effective implementation of formative assessment were student learning, 42,8\% (9/21), teacher beliefs, and being time-consuming, 33,3\% (7/21), and finally, being an examination- oriented culture and heavy workload, 28,5\% (6/21). It is likely that changing teachers for formative assessment is not a "quick fix" as Black and Wiliam (1998) mentioned in their first review. The results of this review support this point. In the following sub-sections, three levels of contextual factors and two barriers to formative assessment practice will be discussed.

\subsection{Micro Level}

\subsubsection{Teacher Knowledge}

Based on the findings of our review, teacher knowledge is the biggest factor in the implementation of formative assessment. In most of the reviewed studies, teachers did not understand the concept of formative assessment is or how to implement it. For example, in the studies by Wan Ka, Kim Wai Raymond and Kwok On (2006), 56\% and 66,5\% of the Physical Education teachers, respectively agreed that these two issues were the most important. In a case study of two teachers by Chen, May, Klenowski, and Kettle (2014), despite a lack of knowledge and training in formative assessment, the teachers were able to implement assessment tasks efficiently. Additionally, their actual practice was positive in that they provided specific, supportive and timely oral feedback to student presentations. However, there was a lack of student engagement in self-assessment or peer-assessment due to the barrier of power distance and hierarchy in Asian culture. Teachers are the only source of feedback in the classroom.

Malaysian lecturers were most capable of communicating assessment results and feedback in 
a national survey of competency of formative assessment. Nevertheless, there was no evidence that the feedback given was used in a critical way, for example, using student learning information for further learning (Tunku Badariah Tunku Ahmad, et al., 2014). This is a crucial problem as the lack of understanding of formative assessment (internal barrier) makes it more difficult for teachers to control and overcome other external obstacles.

In fact, four studies which did not refer to the need for teacher training also faced additional challenges from three levels of contextual factors and two inherent disadvantages of formative assessment. All of this indicates that conducting formative assessment is not a straightforward task in Asia. Despite teacher competency, teacher practice of formative assessment was shown to be inconsistent, irregular and constrained by various contextual challenges (Mak \& Lee, 2014). Unless teachers are able to conduct formative assessment in flexible ways for different students and different circumstances, there will be an increasing effect on formative assessment (Darling-Hammond, 2006).

Notwithstanding the above, very few formative assessment studies in Asia have paid attention to developing professional programs for Asian teachers. Only one of the studies by Yin \& Buck (2015), reported a participant teacher's training in formative assessment practice through collaborative action research for seven weeks. Such a short duration of training is insufficient to enhance teacher knowledge and skills thoroughly, and its effect cannot be measured by student achievement. Hence there is a significant need for future work in this area to design teacher training programs by examining changes in teachers' knowledge and skills, and by measuring how their improvement affects student learning. A professional development program not only builds teacher capability to practice formative assessment, but also gradually changes their long-held beliefs of teaching and learning methods which previously impeded teachers' practices. The fact is changing the cultural beliefs of teachers, which have been handed down from generation to generation, is an arduous task.

\subsubsection{Teacher Beliefs toward Teaching, Learning and Assessment}

Teacher beliefs toward teaching, learning and assessment represent another challenge for implementing formative assessment in this region. Asian teachers believe that students need to master the basic knowledge in the textbook by memorizing and drilling, preferring the "only-right-answer" approach. This is exemplified in the study by Yin and Buck (2015), where the teacher sought predetermine correct answers without giving an opportunity for classroom discussion generated by follow-up questions to enhance student thinking. Similarly, in the study by Chen, Crockett, Namikawa, Zilimu, and Lee (2012), students with low academic capacity were made to believe that they could only learn mathematics by memorizing basic knowledge from the textbook. Such teacher beliefs make formative assessment practice more rigid and tense. As they contradict formative assessment principles where student thinking and their involvement in the learning process are the most significant evidence of good teaching and learning.

Moreover, teacher conceptions of assessment in Asia has been deemed unsuitable for the implementation of formative assessment. Some Singaporean music teachers felt they were not good teachers if they did not assess students or grade them (Leong, 2014a). Also, Hong 
Kong primary EFL teachers thought that the final version of students' writing had to be perfect with no mistakes. As a result, these teachers stopped using focused corrective feedback as outlined in formative assessment research and returned instead to direct corrective feedback, reinforcing their former school tradition (Mak \& Lee, 2014).

This belief in the traditional role of the teachers expresses itself from generation to generation, starting from a teacher's own learning experience, upheld by their families, and later carried on as student beliefs. Therefore, changing teacher beliefs is as demanding as changing student learning.

\subsubsection{Student Learning}

Asian student learning conflicts with the principles of formative assessment, particularly in self-assessment and peer-assessment. Lam (2013) aimed to use the Formative Use of Summative Test (FUST) technique to improve student learning by self-assessment. However, low-achieving students did not experience the same noticeable effect as high achieving ones. They had a less serious attitude towards this technique in comparison to teacher assessment, and a less confident in preparing their own tests. Furthermore, students refrained from asking questions when they were uncertain about the answers in order to avoid "losing face" Also, students were often confused on how to do self-assessment and peer-assessment; it seemed difficult to compare their own work with that of their peers (Pham \& Renshaw, 2015; Yin \& Buck, 2015).

Even though Asian students are somewhat motivated to do peer-assessment due to the reduced pressure and stress compared to teacher assessment, they still favor teacher feedback as they feel it is more accurate and detailed than peer-assessment (Chen et al., 2014; $\mathrm{Ng}$, 2014; Tepsuriwong \& Bunsom, 2013). This kind of belief originated from Confucian culture, which highlights the teacher's role in transferring knowledge to society. To effectively deal with these concerns, learners should be guided carefully and provided with concrete examples to understand the general methodology of doing self-assessment and peer-assessment (Black, 2015; Ng, 2014).

\subsubsection{Big Class}

Biggs (1998) claimes that large class size does not diminish effective teaching in Asia. However, large class sizes do interfere with the efforts of Asian teachers to implement educational innovations, such as collaborative teaching (Pham, 2014) or formative assessment (See Table 1). As formative assessment focuses on improving individual student learning based on relevant feedback from different students' needs. A larger number of students per classroom would make it more difficult for the teacher to implement formative assessment. Teachers need to spend more time and attention in order to provide feedback. It it stressful and impractical for teachers within the limited duration of a 40-minute class. Chen et al. (2014) gave the example of one university teacher in China, who acknowledged that giving individual feedback in a big class was tough, even though she was proud of her ability to be personally acquainted with all the students in her classes.

In large lectures, the use of technology to implement formative assessment is a step in the 
right direction. For example, the use of clickers to help elicit quick responses from students while learning in class (Ludvigsen, Krumsvik, \& Furnes, 2015), or conducting formative assessment with the aid of various technology such as computers, mobile, and PDA (Hung et al., 2010; Hwang \& Chang, 2011; Miller, 2009; Wang, 2007). However, this solution only works with careful design and adequate preparation. In addition, some developing Asian countries with a limited budget for education cannot afford these modern technologies. Thus, a promising direction for future research would be to investigate new formative assessment activities which are more compatible with Asian institutional conditions.

\subsection{Meso Level and Macro Level}

Although the three levels of Kozma's model are separate, micro and meso levels are mostly affected by the macro level, in which the testing culture is a major influence. For instance, school authorities do not support teachers'attempts at formative assessment techniques which could affect student performance on summative assessments. Also, by focusing on summative assessment, some schools do not give teachers enough autonomy to allow them to be creative in their own teaching. Teachers who are desirous of implementing formative assessment struggle to carry on numerous research projects without the support of school authorities or colleagues, and had the additional burden of keeping up with the school syllabus (Leong, 2014a; Mak \& Lee, 2014).

Furthermore, school authorities did not accept solely formative feedback on student writings, and demanded that teachers using this method should also drill students by writing ten papers before the semester test (Mak \& Lee, 2014). In the research conducted by Ratnam-Lim et al.(2015), teachers trying to implement formative assessment were forced to teach test skills to students through many small tests and quizzes. It is clear that the testing culture has been discouraging Asian teachers' efforts to conduct formative assessment.

Time-consuming nature and the additional workload are the two disadvantages of formative assessment practice. The interaction between these drawbacks and the three levels of contextual barriers creates a huge amount of tension in attempts to implement formative assessment in the Asian classroom. As a result, most Asian teachers in the studies reviewed were reluctant to integrate formative assessment into their daily teaching.

Teachers play the biggest role in overcoming these barriers. Alisha, the teacher in the case study of Leong (Leong, 2014a) successfully integrated classroom assessment in teaching English at a Singapore primary school. Taking advantage of her experience as a research assistant, training in formative assessment and with her school leaders' supports, Alisha had both a profound understanding of formative assessment and a strong motivation to practice it despite the challenges of a test-oriented culture. While her colleagues were afraid of implementing self- and peer-assessment due to its time-consuming nature, her belief was that formative assessment would help students learn and improve from their own errors. Her success with this approach motivated her to balance the heavy teaching workload by writing detailed feedback on her students' daily work. In other words, this case study demonstrated that teacher knowledge on formative assessment, personal beliefs on how it can positively impact teaching and learning, and the support of school authorities increase the success rate 
of formative assessment practice in Asian countries.

\section{Conclusion}

The results of our review and such case studies as that of Alisha shed light on the solution for improving formative assessment practice in Asia. Careful teacher training and providing support to them should be a priority. The important question is how to educate teachers in order to implement formative assessment efficiently. From the results of their review regarding teacher assessment literacy, Xu and Brown (2016) propose a three-level framework of teacher assessment literacy in practice. They are the assessment knowledge base; teacher conception of assessment and teacher identity as an assessor. These authors also emphasize two ways for teacher learning to master these levels. First, they have to constantly reflect their own practices to connect what they do and how they can improve their assessment effectiveness. Second, teachers need to participate in community activities where they practice, discuss and negotiate their conception of assessment with other teachers' ideas. Currently, Singapore is the only country known to conduct a long-term professional development programs on assessment for learning among primary teachers (Fangxi, Teng, Tan, \& Peng, 2014). More studies on this issue with particular attention to what forms an effective training program for Asian teachers as measured by student performance on summative assessments should be carried out by researchers in this field.

In addition, as a short term solution, action research or lesson learning are appropriate research methods that could help local teachers investigate types of formative assessment practice that would be effective in their own classroom and context (Smith, 2013). Research aimed at developing new formative assessment activities to expand the formative assessment theory to include measures to deal with the specific Asian contextual barriers mentioned in the literature is necessary in order to provide teachers with workable instructions on how to implement formative assessment within the Asian classrooms.

Some limitations need to be considered. First, this review may have overlooked some studies on formative assessment in the Asian region due to the different terms used by authors to refer to formative assessment. Second, this review solely examined challenges in formative assessment with respect to Kozma's model; there might be other models for analyzing the contextual contradiction of facilitating educational innovation in Asian classroom (See Zhang, 2010).

In summary, this review brings to light the current major problems in implementing formative assessment in Asia. This includes investing in teachers with knowledge on formative assessment, supporting teacher practice in the classroom, the underlying challenges at all three levels of contextual factors and the two inherent disadvantages of formative assessment. It is hoped that this review will draw attention to these issues from local teachers, school authorities, as well as educational policymakers, so that future generations will benefit from the substantial advantages to be gained by employing formative assessment suited to the Asian culture and institutional infrastructure. 
Table 1. Challenge categories of formative assessment (FA) practice in Asian countries

\begin{tabular}{|c|c|c|c|c|c|c|c|c|c|c|c|c|}
\hline \multirow{3}{*}{ Author, year } & \multirow{3}{*}{ Location } & \multirow{3}{*}{$\begin{array}{l}\text { School } \\
\text { level }\end{array}$} & \multicolumn{10}{|c|}{ Challenge categories of formative assessment practice } \\
\hline & & & \multicolumn{4}{|c|}{ Micro- level } & \multicolumn{3}{|c|}{ Meso- level } & \multirow{2}{*}{\begin{tabular}{|l}
$\begin{array}{l}\text { Macro- } \\
\text { level }\end{array}$ \\
$\begin{array}{l}\text { EO } \\
\text { culture }\end{array}$
\end{tabular}} & \multicolumn{2}{|c|}{$\begin{array}{l}\text { Primary } \\
\text { disadvantage } \\
\text { s of FA }\end{array}$} \\
\hline & & & $\begin{array}{l}\mathrm{T} \\
\mathrm{K}\end{array}$ & $\begin{array}{l}\mathrm{T} \\
\mathrm{Bs}\end{array}$ & $\begin{array}{l}\mathrm{S} \\
\mathrm{L}\end{array}$ & $\begin{array}{l}\mathrm{B} \\
\mathrm{C}\end{array}$ & $\begin{array}{l}\mathrm{S} \\
\mathrm{A}\end{array}$ & $\begin{array}{l}\mathrm{S} \\
\mathrm{C}\end{array}$ & $\begin{array}{l}\text { LD in } \\
\text { school }\end{array} \mid$ & & $\mathrm{T}-\mathrm{C}$ & $\begin{array}{l}\mathrm{H} \\
\mathrm{WL}\end{array}$ \\
\hline $\begin{array}{l}\text { Wan Ka, Kim } \\
\text { Wai Raymond, \& } \\
\text { Kwok On }(2006)\end{array}$ & $\begin{array}{l}\text { Hong } \\
\text { Kong }\end{array}$ & $\begin{array}{l}\text { Secondar } \\
\mathrm{y}\end{array}$ & + & & & + & & + & + & & + & \\
\hline $\begin{array}{l}\text { Perera, Lee, Win, } \\
\text { Perera, \& } \\
\text { Wijesuriya } \\
(2008)\end{array}$ & Malaysia & College & + & + & + & & & & & & & \\
\hline $\begin{array}{lll}\text { Chin } & \& & \text { Teou } \\
(\text { Chin } & \& & \text { Teou, } \\
2010) & & \end{array}$ & $\begin{array}{l}\text { Singapor } \\
\mathrm{e}\end{array}$ & Primary & & & & + & & & & & + & + \\
\hline $\begin{array}{l}\text { Kemp \& Scaife } \\
\text { (Kemp \& Scaife, } \\
\text { 2012) }\end{array}$ & $\begin{array}{l}\text { Singapor } \\
\mathrm{e}\end{array}$ & College & + & & & & & & & & & \\
\hline $\begin{array}{l}\text { Chen, Crockett, } \\
\text { Namikawa, } \\
\text { Zilimu, \& Lee } \\
(2012)\end{array}$ & Taiwan & $\begin{array}{l}\text { Secondar } \\
\mathrm{y}\end{array}$ & + & + & & & & & & & & \\
\hline $\begin{array}{l}\text { Tepsuriwong \& } \\
\text { Bunsom (2013) }\end{array}$ & Thailand & College & + & & + & & & & & & & \\
\hline $\begin{array}{l}\text { Chen, Kettle, } \\
\text { Klenowski, } \\
\text { \&May (2013) }\end{array}$ & China & College & + & + & + & & & + & & + & & \\
\hline Lam (2013) & $\begin{array}{l}\text { Hong } \\
\text { Kong }\end{array}$ & Primary & + & & + & & & & & & + & \\
\hline $\begin{array}{l}\text { Mak \& Lee (Mak } \\
\& \text { Lee, 2014) }\end{array}$ & $\begin{array}{l}\text { Hong } \\
\text { Kong }\end{array}$ & Primary & & + & & & + & + & + & + & + & + \\
\hline $\begin{array}{l}\text { Leong (Leong, } \\
\text { 2014a) }\end{array}$ & $\begin{array}{l}\text { Singapor } \\
\text { e }\end{array}$ & Primary & & rep & rted & & & & & & & \\
\hline Leong (2014b) & $\begin{array}{l}\text { Singapor } \\
\text { e }\end{array}$ & $\begin{array}{l}\text { Primary, } \\
\text { Secondar } \\
\text { y,College }\end{array}$ & + & + & & & & & & & & \\
\hline
\end{tabular}




\begin{tabular}{|c|c|c|c|c|c|c|c|c|c|c|c|}
\hline & & $\begin{array}{l}\text { and } \\
\text { Ministry }\end{array}$ & & & & & & & & & \\
\hline $\mathrm{Ng}(\mathrm{Ng}, 2014)$ & $\begin{array}{l}\text { Hong } \\
\text { Kong }\end{array}$ & College & + & & + & & & & & & \\
\hline $\begin{array}{l}\text { Abbasnasab } \\
\text { Sardareh \& } \\
\text { Sedigheh (2014) }\end{array}$ & Malaysia & Primary & + & & & & & & & & \\
\hline $\begin{array}{l}\text { Talib et al. } \\
(2014)\end{array}$ & Malaysia & Primary & + & & & & & & & & \\
\hline $\begin{array}{l}\text { Tunku Badariah } \\
\text { Tunku Ahmad et } \\
\text { al. (2014) }\end{array}$ & Malaysia & College & + & & & & & & & & \\
\hline $\begin{array}{l}\text { Chen, May, } \\
\text { Klenowski, \& } \\
\text { Kettle (Q. Chen } \\
\text { et al., 2014) }\end{array}$ & China & College & + & + & + & + & & & & & \\
\hline $\begin{array}{l}\text { Yan \& Cheng, } \\
(2015)\end{array}$ & $\begin{array}{l}\text { Hong } \\
\text { Kong }\end{array}$ & Primary & + & & & + & & & + & & + \\
\hline $\begin{array}{l}\text { Ratnam-lim, } \\
\text { Heng, } \\
\operatorname{Tan}(2015)\end{array}$ & $\begin{array}{l}\text { Singapor } \\
\mathrm{e}\end{array}$ & Primary & + & & & & + & + & + & + & + \\
\hline$\underset{(2015)}{\text { Yin \& Buck }}$ & China & $\begin{array}{l}\text { Secondar } \\
\mathrm{y}\end{array}$ & + & & + & + & & & + & + & \\
\hline $\begin{array}{l}\text { Pham \& } \\
\text { Renshaw (2015) }\end{array}$ & Vietnam & College & & & + & & & + & + & & + \\
\hline $\begin{array}{l}\text { Al-Wassia, } \\
\text { Hamed, } \\
\text { Al-Wassia, } \\
\text { Alafari, } \quad \text { \& } \\
\text { Jamjoom (2015) }\end{array}$ & $\begin{array}{l}\text { Saudi } \\
\text { Arabia }\end{array}$ & College & + & + & + & & & & + & + & \\
\hline
\end{tabular}

Notes:

1. In 10 columns of challenge categories of formative assessment practice: + indicates the study did mention the challenge.

2. Abbreviation: TK: Teacher knowledge; TBs: Teacher beliefs; SL: Student learning; BC:Big class; SA: Shool authority; SL: School culture; LD in school: Labour division in school; EO culture: Examination-oriented culture; T-C: Time-consuming; H WL: Heavy workload. 


\section{Acknowledgement}

This publication is supported by the USM-VIED Fellowship, Universiti Sains Malaysia to the first author.

\section{References}

Abbasnasab, S. S., \& Sedigheh, A. S. (2014). Assessment for learning in a Malaysian ESL primary school context. Faculty of Education. University Malaysia.

Akom, G. V. (2010). Using formative assessment despite the constraints of high stakes testing and limited resources: A case study of chemistry teachers in Anglophone Cameroon. Western Michigan University. Western Michigan University, Ann Arbor.

Al-Wassia, R., Hamed, O., Al-Wassia, H., Alafari, R., \& Jamjoom, R. (2015). Cultural challenges to implementation of formative assessment in Saudi Arabia: An exploratory study. Medical Teacher, 37, S9-S19. https://doi.org/10.3109/0142159x.2015.1006601

Andersson, C. (2015). Professional development in formative assessment: Effects on teacher classroom practice and student achievement. Department of Science and Mathamatics Education. Umea University. Retrieved from http://diva-portal.org/smash/get/diva2:807530/FULLTEXT01

Asghar, A. (2009). Reciprocal peer coaching and its use as a formative assessment strategy for first - year students. Assessment \& Evaluation in Higher Education, 35(4), 403-417. https://doi.org/10.1080/02602930902862834

Bennett, R. E. (2011). Formative assessment: a critical review. Assessment in Education: Principles, Policy \& Practice, 18(1), 5-25. Retrieved from http://www.tandfonline.com/doi/pdf/10.1080/0969594X.2010.513678

Berry, R. (2011a). Educational Assessment in Mainland China, Hong Kong and Taiwan. In R. Berry, \& B. Adamson (Eds.), Assessment Reform in Education: Policy and Practice (Vol. 14, pp. 49-61). Springer Netherlands. https://doi.org/10.1007/978-94-007-0729-0_4

Berry, R. (2011b). Profiles of education assessment systems worldwide: Assessment trends in Hong Kong: seeking to establish formative assessment in an examination culture. Assessment in Education, 18(2), 199. http://dx.doi.org/10.1080/0969594X.2010.527701

Biggs, J. (1998). Learning from the Confucian heritage: so size doesn't matter? International $\begin{array}{llll}\text { Journal of } & \text { Educational } & \text { 723-738. }\end{array}$ https://doi.org/http://dx.doi.org/10.1016/S0883-0355(98)00060-3

Black, P. (2015). Formative assessment - an optimistic but incomplete vision. Assessment in Education: Principles, Policy \& Practice, 22(February), 37-41. https://doi.org/10.1080/0969594X.2014.999643

Black, P., \& Wiliam, D. (1998). Inside the Black Box: Raising Standards Through Classroom Assessment. Phi Delta Kappan, 80(2), 139-148. https://doi.org/10.1002/hrm

Bloom, B. S., Hastings, J. T., \& Madaus, G. F. (1971). Handbook on formative and summative evaluation of student learning. Techniques. New York: McGraw-Hill. Retrieved from http://eric.ed.gov/ERICWebPortal/search/detailmini.jsp?_nfpb=true\&_\&ERICExtSearch_Sea rchValue_0=ED049304\&ERICExtSearch_SearchType_0=no\&accno=ED049304 
Carless, D. (2005). Prospects for the implementation of assessment for learning. Assessment in Education: Principles, Policy \& Practice, 12(1), 39-54. https://doi.org/10.1080/0969594042000333904

Carless, D. (2012). From testing to productive student learning: implementing formative assessment in Confucian-heritage settings (Kindle edition). New York: Routledge. https://doi.org/10.1080/0969594X.2011.632863

Chen, C. H., Crockett, M., Namikawa, T., Zilimu, J., \& Lee, S. (2012). Eighth grade mathematics teachers' formative assessment practices in ses-different classrooms: A taiwan study. International Journal of Science \& Mathematics Education, 10(3), 553-579. https://doi.org/10.1007/s10763-011-9299-7

Chen, J. (2015). Formative assessment as a vehicle for changing classroom practice in a specific cultural context. Cultural Studies of Science Education, 1-10. https://doi.org/10.1007/s11422-014-9599-7

Chen, Q., Kettle, M., Klenowski, V., \& May, L. (2013). Interpretations of formative assessment in the teaching of English at two Chinese universities: a sociocultural perspective. Assessment \& Evaluation in Higher Education, 38(7), 831-846. https://doi.org/10.1080/02602938.2012.726963

Chen, Q., May, L., Klenowski, V., \& Kettle, M. (2014). The enactment of formative assessment in English language classrooms in two Chinese universities: teacher and student responses. Assessment in Education, 21. https://doi.org/10.1080/0969594X.2013.790308

Chin, C., \& Teou, L.-Y. (2010). Formative assessment: Using concept cartoon, pupils' drawings, and group discussions to tackle children's ideas about biological inheritance. Journal of Biological Education, 44(3), 108-115. https://doi.org/10.1080/00219266.2010.9656206

Clark, I., \& Li, M. (2013). Efficacy of Formative Classroom Assessments in Theory and Practice. College of Education. University of Washington. Retrieved from https://dlib.lib.washington.edu/researchworks/bitstream/handle/1773/25024/Clark_washingto n_0250E_12456.pdf? sequence $=1 \&$ isAllowed $=\mathrm{y}$

Crick, R. D., Broadfoot, P., \& Claxton, G. (2004). Developing an Effective Lifelong Learning Inventory: the ELLI Project. Assessment in Education: Principles, Policy \& Practice, 11(3), 247-272. https://doi.org/10.1080/0969594042000304582

Darling-Hammond, L. (2006). Constructing 21st-Century Teacher Education. Journal of Teacher Education, 57(3), 300-314. https://doi.org/10.1177/0022487105285962

Falk, A. (2011). Teachers learning from professional development in elementary science: Reciprocal relationships between formative assessment and pedagogical content knowledge. Science Education. https://doi.org/10.1002/sce.20473

Fangxi, T., Teng, E., Tan, J., \& Peng, Y. W. (2014). Holistic Assessment Implementation in Singapore Primary Schools-Part II: Developing Teacher Assessment Capacity to Improve Student Learning. In International Association of Educational Assessment Conference. Singapore. Retrieved from www.iaea.info/documents/paper_226dc1b5b9.pdf 
Fulmer, G. W., Lee, I. C. H., \& Tan, K. H. K. (2015). Multi-level model of contextual factors and teachers' assessment practices: an integrative review of research. Assessment in Education: $\quad$ Principles, $\quad$ Policy $\&$ Practice, $1-20$. https://doi.org/10.1080/0969594X.2015.1017445

Hodgson, P., \& Pang, M. Y. C. C. (2012). Effective formative e-assessment of student learning: a study on a statistics course. Assessment and Evaluation in Higher Education, 37(2), 215. https://doi.org/10.1080/02602938.2010.523818

Hoskins, B., \& Fredriksson, U. (2008). Learning to Learn: What is it and can it be measured. Joint Research Centre Technical Report JRC.

Hung, P. H., Lin, Y. F., \& Hwang, G. J. (2010). Formative assessment design for PDA integrated ecology observation. Educational Technology and Society, 13(3), 33-42.

Hutchinson, C., \& Hayward, L. (2005). The journey so far: assessment for learning in Scotland. Curriculum Journal, 16(2), 225-248. https://doi.org/10.1080/09585170500136184

Hwang, G.-J., \& Chang, H.-F. (2011). A formative assessment-based mobile learning approach to improving the learning attitudes and achievements of students.pdf. Computers \& Education, $56(4)$,

1023-1031.

https://doi.org/http://dx.doi.org/10.1016/j.compedu.2010.12.002

Jackson, M., \& Marks, L. (2015). Improving the effectiveness of feedback by use of assessed reflections and withholding of grades. Assessment \& Evaluation in Higher Education, 1-16. https://doi.org/10.1080/02602938.2015.1030588

Jingzheng, W., \& Yuanbing, D. (2014). Conducting Web-based Formative Assessment Reform for ODL Students: A Case Study. Journal of Language Teaching \& Research, 5(3), 654-662. https://doi.org/10.4304/jltr.5.3.654-662

Kemp, S., \& Scaife, J. (2012). Misunderstood and neglected? Diagnostic and formative assessment practices of lecturers. Journal of Education for Teaching, 38(2), 181-192. https://doi.org/10.1080/02607476.2012.656443

Kennedy, K. J. (2007). Barriers to Innovative School Practice: A Socio-Cultural Framework for Understanding Assessment Practices in Asia. "Student Assessment and Its Social and Cultural Contexts: How Teachers Respond to Assessment Reforms". Redesigning PedagogyCulture, Understanding and Practice Conference,. Nanyang Technological University, National Institute of Education, Centre for Research in Pedagogy and Practice.

Klenowski, V. (2009). Assessment for Learning revisited: an Asia-Pacific perspective. Assessment in Education: Principles, Policy \& Practice, 16(3), 263-268. https://doi.org/10.1080/09695940903319646

Lam, R. (2013). Formative Use of Summative Tests: Using Test Preparation to Promote Performance and Self-Regulation. The Asia-Pacific Education Researcher, 22(1), 69-78. https://doi.org/10.1007/s40299-012-0026-0

Leong, W. S. (2014a). Knowing the intentions, meaning and context of classroom assessment: A case study of Singaporean teacher's conception and practice. Studies in Educational Evaluation, 43(0), 70-78. https://doi.org/http://dx.doi.org/10.1016/j.stueduc.2013.12.005

Leong, W. S. (2014b). Understanding classroom assessment in dilemmatic spaces: case 
studies of Singaporean music teachers' conceptions of classroom assessment. Music Education Research, 16(June), 1-17. https://doi.org/10.1080/14613808.2013.878325

Ludvigsen, K., Krumsvik, R., \& Furnes, B. (2015). Creating Formative Feedback Spaces in Large Lectures. Computers \& Education, 88(0), 48-63. https://doi.org/10.1016/j.compedu.2015.04.002

Mak, P., \& Lee, I. (2014). Implementing assessment for learning in L2 writing: An activity theory perspective. System, 47, 73-87. https://doi.org/10.1016/j.system.2014.09.018

Miller, T. (2009). Formative computer-based assessment in higher education: the effectiveness of feedback in supporting student learning. Assessment \& Evaluation in Higher Education, 34(2), 181-192. https://doi.org/10.1080/02602930801956075

Mok, K.-H., \& Chan, D. K. K. (2002). Globalization and education: the quest for quality education in Hong Kong (Vol. 1). Hong Kong University Press.

$\mathrm{Ng}$, E. M. W. (2014). Using a mixed research method to evaluate the effectiveness of formative assessment in supporting student teachers' wiki authoring. Computers and Education, 73, 141-148. https://doi.org/10.1016/j.compedu.2013.12.016

OECD. (2005). Formative Assessment: Improving Learning in Secondary Classrooms. Assessment (Vol. 29). Pairs, France: Centre for Educational Research and Innovation/Organization for Economic Cooperation and Development. https://doi.org/www.oecd.org/dataoecd/19/31/35661078.pdf

OECD. (2008). OECD/CERI International Conference "Learning in the 21st Century: Research, Innovation and Policy." 21St Century Learning: Research, Innovation and Policy Directions From Recent Oecd Analyses. Pairs, France: Organisation for Economic Co-operation and Development. Retrieved from www.oecd.org/dataoecd/39/8/40554299.pdf

Perera, J., Lee, N., Win, K., Perera, J., \& Wijesuriya, L. (2008). Formative feedback to students: the mismatch between faculty perceptions and student expectations. Medical Teacher, 30(4), 395-399. https://doi.org/10.1080/01421590801949966

Pham, T. H. T. (2014). Implementing Cross-culture Pedagogies: Cooperative Learning at Confucian Heritage Cultures (Vol. 25). Springer Science \& Business Media.

Pham, T. H. T., \& Renshaw, P. (2015). Formative assessment in Confucian heritage culture classrooms: activity theory analysis of tensions, contradictions and hybrid practices. Assessment \& Evaluation in Higher Education, 40(1), 45-59. https://doi.org/10.1080/02602938.2014.886325

Ratnam-Lim, C. T. L., Heng, K., \& Tan, K. (2015). Large-scale implementation of formative assessment practices in an examination-oriented culture. Assessment in Education: Principles, Policy \& Practice, 22(1), 61-78. https://doi.org/10.1080/0969594X.2014.1001319

Smith, K. (2013). Formative assessment of teacher learning: issues about quality, design characteristics and impact on teacher learning. Teachers and Teaching, 19(2), 228-234. https://doi.org/10.1080/13540602.2013.741835

Talib, R., Kamsah, M. Z., Naim, H. A., Latif, A. A., Abu Naim, H., \& Abdul Latif, A. (2014). From Principle to Practice : Assessment for Learning in Malaysian School-Based Assessment Classroom. International Journal of Social Sciences \& Education, 4(4), 850-857. Retrieved 
from

http://connection.ebscohost.com/c/articles/97082929/from-principle-practice-assessment-lear ning-malaysian-school-based-assessment-classroom

Tepsuriwong, S., \& Bunsom, T. (2013). Introducing peer assessment to a reading classroom: Expanding Thai university students' learning boundaries beyond alphabetical symbols. Mediterranean Journal of Social Sciences, 4(14), 279-286. https://doi.org/10.5901/mjss.2013.v4n14p279

Tunku Badariah Tunku Ahmad, Ainol Madziah Zubairi, Mohd Burhan Ibrahim, Joharry Othman, Nik Suryani Abd Rahman, Zainurin Abd Rahman, Mohamad Sahari Nordin, Z. M. N. (2014). Assessment for learning practices and competency among malaysian university lecturers: a national study. Practitioner Research In Higher Education, 8, 14-31. Retrieved from http://194.81.189.19/ojs/index.php/prhe/article/viewFile/171/282

Wan Ka, C., Kim Wai Raymond, S., \& Kwok On, L. (2006). Barriers to the Implementation of Physical Education (PE) Assessment in Hong Kong. International Journal of Learning, 13(4), 165-170.

Wang, T. H. (2007). What strategies are effective for formative assessment in an e-learning environment? Journal of Computer Assisted Learning, 23(3), 171-186. https://doi.org/10.1111/j.1365-2729.2006.00211.x

Wen, M. L., \& Tsai, C.-C. (2006). University Students' Perceptions of and Attitudes Toward (Online) Peer Assessment. Higher Education, 51(1), 27-44. https://doi.org/10.1007/s10734-004-6375-8

Wiliam, D. (2011). What is assessment for learning? Studies in Educational Evaluation, 37(1), 3-14. https://doi.org/10.1016/j.stueduc.2011.03.001

Wiliam, D., \& Thompson, M. (2008). Intergrating assessment with learning: What will it take to make it work? In C. A. Dweyer (Ed.), The future of assessment: Shaping teaching and learning (pp. 53-82). New York: Erlbaum.

$\mathrm{Xu}$, Y., \& Brown, G. T. L. (2016). Teacher assessment literacy in practice: A reconceptualization. Teaching and Teacher Education, 58, 149-162. https://doi.org/10.1016/j.tate.2016.05.010

Yan, Z., \& Cheng, E. C. K. (2015). Primary teachers' attitudes, intentions and practices regarding formative assessment. Teaching and Teacher Education, 45, 128-136. https://doi.org/10.1016/j.tate.2014.10.002

Yin, X., \& Buck, G. a. (2015). There is another choice: an exploration of integrating formative assessment in a Chinese high school chemistry classroom through collaborative action research. Cultural Studies of Science Education, 1-34. https://doi.org/10.1007/s11422-014-9572-5

Yin, X., \& Buck, G. A. (2013). Negotiating the use of formative assessment for learning in an era of accountability testing. Indiana University, Ann Arbor. Retrieved from http://search.proquest.com/docview/1461462265? accountid=14645

Zhang, J. (2010). Technology-supported learning innovation in cultural contexts. Educational Technology

Research

and

Development,

$58(2)$,

229-243. 


\section{Macrothink}

Journal of Social Science Studies

ISSN 2329-9150

2017, Vol. 4, No. 1

https://doi.org/10.1007/s11423-009-9137-6

\section{Copyright Disclaimer}

Copyright for this article is retained by the author(s), with first publication rights granted to the journal.

This is an open-access article distributed under the terms and conditions of the Creative Commons Attribution license (http://creativecommons.org/licenses/by/3.0/). 